УДК 811.161.2’282

DOI https://doi.org/10.26661/2414-9594-2021-1-8

\title{
КОЛОКАЦІЇ У СКЛАДІ МОНОГОВІРКОВОГО ТЕЗАУРУСА
}

\author{
Громко Т. В. \\ кандидат філологічних наук, \\ доиент кафедри украӥнської мови \\ Центральноукрайнський державний педагогічний університет імені Володимира Винниченка \\ вул. Шевченка, 1, Кропивницький, Україна \\ orcid.org/0000-0002-4661-4302 \\ hromkot@gmail.com
} Ключові слова: говірка,
моноговіркова дескрипизія,
тезаурус, говірколінгварій,
мовно-мовленнєві одиниці,
колокація, лексикографування.
У статті теоретично обгрунтовується місце колокацій як мовно-мовленнєвих одиниць у говірковому дискурсі, що визначає їхній лексикографічний ранг у тезаурусі говірки. Колокація $є$ неоднослівним, стійким і таким, що регулярно трапляється в мовленні, словосполученням, що позначає єдине поняття, i, ієрархічно знаходячись між словом і фразеологізмом як одиницями мовних виражень, є реалізацією полісемії слів. Такі конструкції важливі для дескрибування мовних даних говірки, що вилучені з мовленнєвих текстів на основі врахування граматико-синтагматичних зв'язків. Звернено увагу на можливості корпусного підходу до відбору таких одиниць та подальшу наукову інтерпретацію колокаційної складової частини в системі говірки у складі монографічного опису. Вокабуляр тезауруса, фрагмент якого подається, базується на токенізації, своєрідній декомпозиції текстового матеріалу на ряд мовних одиниць - слів та колокацій тощо. За такого методу лексикографування застосовуються дистрибутивний i контекстологічний методи. Пропонований автором аналіз лексично-граматичного рівня емпіричного матеріалу говірки як системи мови $є$ фрагментом іiі дескрипції, що в межах опису моноговіркового лінгварію передбачає укладання тезауруса. У межах вокабулярію тезауруса колокації кваліфікуються як семантичні графи або смислові одиниці тексту. Звернено увагу на особливості токенізації з текстів усного мовлення та лексикографування колокацій в тезаурусі говірки. Колокації в говірковому дискурсі відрізняються і яскраво вираженою граматичною природою, і стійким характером, і статистичною представленістю в усному колективному мовленні, що $\epsilon$ показником таких активних процесів сучасної української мови, як граматикалізація й ідіоматизація. Лексикографування колокацій у моноговірковому тезаурусі може слугувати базою для укладання окремої колокаційної лексикографічної системи як одного з аспектів екстраполяції говірколінгварію. 


\title{
COLLOCATIONS IN THE MONOIDIOM THESAURUS
}

\author{
Hromko T. V. \\ Candidate of Philological Sciences, \\ Associate Professor at the Ukrainian Language Department \\ Volodymyr Vynnychenko Central Ukrainian State Pedagogical University \\ Shevchenko str., 1, Kropyvnytskyy, Ukraine \\ orcid.org/0000-0002-4661-4302 \\ hromkot@gmail.com
}

Key words: idiom, monoidiom description, thesaurus, idiomolingual, lingual-speech units, colocation, lexicography.
The article theoretically substantiates the place of collocations as languagespeech units in speech discourse, which determines their lexicographic rank in the subdialect thesaurus. Colocation is an ambiguous, stable and regular occurrence in speech, a phrase that denotes a single concept, and, hierarchically between the word and phraseology as units of linguistic expressions, is the realization of the polysema of words. Such constructions are important in describing of the data of speech, which are extracted from subdialect texts on the basis of grammatical-syntagmatic connections. Attention is paid to the possibilities of the corpus approach to the selection of such units and the further scientific interpretation of the collocation component in the speech system as part of a monographic description. The vocabulary of the thesaurus, a fragment of which is presented, is based on tokenization, a kind of decomposition of textual material into a number of language units - words and collocations, etc. Distributive and contextual methods are used in this method of lexicography. The analysis of the lexical and grammatical level of the empirical material of subdialect as a system of language proposed by the author is a fragment of its description, which within the description of the monoidiom linguistics involves the conclusion of a thesaurus. Within the vocabulary of the thesaurus, collocations qualify as semantic graphs or semantic units of text. Attention is paid to the peculiarities of tokenization from oral texts and lexicography of collocations in the thesaurus of speech. Collocations in the speech discourse are distinguished by a pronounced grammatical nature, and a stable character, and statistical representation in oral collective speech, which is an indicator of such active processes of the modern Ukrainian language as grammaticalization and idiomatization. Lexicography of collocations in the monoidiom thesaurus can serve as a basis for concluding a separate collocation lexicographic system as one of the aspects of extrapolation of the speech language.
Постановка проблеми. Дослідження усного розмовного мовлення як багатоаспектний підхід до лінгвістичного осягнення сфери людської комунікації $є$ актуальним щодо діалектних даних 3 погляду аналізу мовно-мовленнєвого матеріалу. Сучасна текстоцентрична орієнтованість українських діалектологічних студій не лише спрямована на фіксацію текстів чи типологічного аспекту граматичних особливостей, а й спроможна в результаті докладного вивчення особливостей усного діалектного мовлення претендувати на аналіз граматики текстів [11], наприклад, у плані колоквіалістики. Колоквіалістичні одиниці $є$ виокремленими 3 текстів окремими конструкціями, що знаходяться на межі лексичного і граматичного рівнів системи мови, мовними виразами, у яких «є аспект плану вираження або плану змісту, що не виводиться зі значення або форми складових частин» [7, с. 19]. До них належать колокації та колігації, які в межах діалектологічного вивчення спроможні подати новий погляд на реалізацію певних слів у складі словосполучень на корпусному текстовому матеріалі, як-от окрему ідіому.

Колокація - це «неоднослівне, стійке і таке, що регулярно трапляється в мовленні» [10, с. 23], словосполучення, що позначає єдине поняття, $\mathrm{i}$, ієрархічно знаходячись між словом і фразеологізмом як одиницями мовних виражень, є реалізацією полісемії слів. Сучасні теоретико-методологічні положення опису колокацій та вивчення їх як феномену, за спостереженнями Т.В. Бобкової, в українському мовознавстві в основному спрямовані на коло питань, які «стосуються системного вивчення лексико-синтаксичної сполучуваності, 
взаємодії внутрішніх форм слів, а також сполучуваності в аспекті лексико-морфологічної та синтаксичної деривації (І.Р. Вихованець, К.Г. Городенська, В.О. Горпинич, Н.В. Гуйванюк, Н.П. Дарчук, А.П. Загнітко, Н.Ф. Клименко, М.П. Кочерган, О.С. Снітко)» $[1$, с. 15$]$.

Мета статті. Лексикологічно колокації не представлені в мовній системі і дотепер мало відображені в академічній лексикографії української мови, оскільки вичленовуються в мовленні на матеріалі значних за обсягом текстових даних. Специфіка цих утворень полягає не тільки у відносній стійкості словосполучень, як перехідному етапі між вільними і фразеологічними словосполученнями, а й у постійній «зустрічальності» номінативних одиниць у межах певної системи мови, що забезпечується повторюваністю у вживанні, частотністю в мовленні, яка, за умови відсутності електронного корпусу текстів, детермінується дослідником текстового матеріалу.

Пропонований нами аналіз лексично-граматичного рівня емпіричного матеріалу говірки як системи мови $є$ фрагментом iї дескрипції, що в межах опису моноговіркового лінгварію передбачає укладання тезауруса. Цей особливий тип словника базується на текстовому корпусі говіркового мовлення і $є$ повним (а не диференційним) за типологічними критеріями. Саме включення до тезауруса колокацій як мовно-мовленнєвих одиниць спонукає до визначення специфіки їх у говірковому мовленні та у відповідному лексикографічному їх представленні.

Виклад основного матеріалу дослідження. Повнота дослідження мовних даних окремої говірки як системи мови (і відображення їі лінгварію в тезаурусі) на контекстно-синтагматичній основі $€$ визначним критерієм виявлення колокацій. Саме типове й постійне оточення слова як мовної одиниці у складі колокації $є$ цілісною одиницею його смислу, незалежно від наповнення та формальної зв'язності цього характерного стійкого сполучення слів. Відомий у лінгвістиці фьорзіанський підхід виділяє: колокації - супровід слова в контексті, або матеріал, у якому воно найчастіше трапляється, і колігації - взаємозв'язані граматичні категорії у синтаксичній конструкції [12, с. 209]. Український дослідник В.В. Левицький віддає перевагу «частоті сумісної вживаності слів і ступеню їх синтагматичної зв'язності» [6, с. 191].

Важливість текстів усного мовлення, що репрезентує говірковий дискурс $[4$, с. 30$]$, полягає не в перевірці таких аспектних характеристик колокацій, з одного боку, завдяки значному розширенню корпусу даних говірки (довготривале укладання корпусу з постійно еліцитованою програмою збирання матеріалу), а 3 іншого - як репрезентаційна база колективного мовного дос- віду в говірковому мовленні. Отже, повнота емпіричного дослідження говірки «безпосередньо у функціонуванні: встановлення значення можливе саме через аналіз уживання форми» [8, с. 344] слів забезпечує виявлення та класифікацію колокацій як особливих конструкцій у їх діалектологічно-лінгвістичній інтерпретації.

Водночас не дескрипція говірки повинна ставити за мету оцінювання і виведення всіх моделей ступеня зв'язності слів, представлених у мовленні. Така фундаментальна їх класифікація 3 погляду наукового жанру має належати монографічному опису говірки, що може бути реалізована в перспективі. Ця можливість визначається не лише моделлю опису, а й повнотою емпіричних даних на синхронічному та діахронічному рівнях тощо. Повний відбір колокацій за корпусним лінгвістичним аналізом спроможний до удокладнення всіх таких конструкцій як неідіоматичних одиниць, яким властиві семантична, синтаксична й дистрибутивна регулярність, за наявності (у перспективі) електронного корпусу говірки, що забезпечує квантитативними методами їх вилучення, статистичними вибірками колокацій, вивчення інтенсивності та селективності сполучуваності слів у мовленні тощо [6, с. 206].

Тезаурус як аспект лексикографічних технологій передбачає документування вилучених із мовленнєвих текстів колокацій як окремих мовних одиниць саме $з$ урахуванням граматико-синтагматичних зв'язків, а також опис колокацій у лексичній системі мови, що становить оптимум «для синхронічного моноговіркового дослідження» [3, с. 13]. Дескрибування говірки як мовної системи передбачає токенізацію, фіксацію в тезаурусі й філіацію значень колокацій, що трапляються в говірковому мовленні. Глибше вивчення говірки - монографічний iї опис - потребує укладання окремої колокаційної лексикографічної системи [9, с. 32], що, очевидно, є запорукою багатоаспектного підходу до такого типу утворень із використанням корпусного методу і єдино правильною методологічною основою дослідження колокацій [2, с. 40].

У складі тезауруса говірки натепер найбільшою мірою репрезентований лінгвістичний потенціал говіркового дискурсу через відповідний моніторинг мовлення носіїв одного населеного пункту говірки села Піщаний Брід Добровеличківського району Центральної України - як перший досвід масштабного лексикографічного опису й оптимум укладання лінгварію окремої говірки. Вокабуляр тезауруса базується не на традиційному для діалектології диференційному виокремленні та тлумаченні мовних одиниць, відмінних від літературного узусу, або діалектнонормативних, а на токенізації, своєрідній декомпозиції текстового матеріалу (що включає весь словниковий його 
склад - діалектного і літературного стратів мови в системі говірки; детальніше див. [5]) на ряд мовних одиниць, інакше кажучи, токенів - слів та колокацій, колігацій тощо - для генерування їх до тезауруса, проводиться автором дослідження вручну й оформляється у відповідні електронні картки. Токенізація колокацій - це сегментація їх як регулярних виразів, оптимізація якої можлива в разі виділення семантичних відношень у тексті.

Методологічно такий відбір колокацій можна кваліфікувати як так званий метод кейсу для лексикографічних даних, що слугує первісним корпусним відбором цих мовних одиниць за говірковими текстами і за цитатними картотеками. Під час лексикографування застосовуються дистрибутивний і контекстологічний методи, які забезпечують урахування лінгвістичних (а не статистичних) ознак сполук за відповідним рангом лексичних чи синтаксичних відношень. Розрізнення слова i колокації як значущих одиниць моноговіркових текстів відбувається не лише за граматичною (синтаксичною) організацією словосполук, а й за лінгвістичними й екстралінгвальними чинниками вербалізації. Якщо аналітично узагальнити, їх можна кваліфікувати як семантичні графи, смислові одиниці тексту, що передаються вокабулою.

Як приклад лексикографування колокацій за даними усного моноговіркового мовлення наводимо фрагмент словникової статті тезауруса (за прийнятими умовними позначеннями, виділення колокації в межах вокабуляру передається знаком $\boldsymbol{\Delta}$ ).

АВТОБУС [аў|тобус], а, ч. Багатомісний автомобіль для перевезення пасажирів. [nри йіхаў на аў|mобус 'i]; [ми ай|тобус на K'іровог'рад]; [Помош'н 'ан 'с 'кий аў|тобус]; [ше Краснопо л'ан'с'кий аў|тобус 'йіздиу]; [аў|тобуси $i$ уночч'i хо|дили]; [ди! / по 'наш' $i$ дороз'i / i malкий комфор'табел'ниц ай|тобус пус'тили]; [ а там йіх посаاдили у сп'іи'і'ал'ний аў|тобус // каже / двое тажн'ї]; [ay̆|mобус не по битий / a во'д'im 'іл'y отв 'ily 'am']; [поў'незний аў|тобус / йак 'кил'ки л'у'дей на'бито // y̆c'iм m'реба 'йіхат']; [йде/ гет' порожн'ій ай|тобус]; [mамкий неўдобний аўтобус]; [ай'тобус

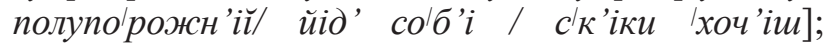
[йа'кийс' а ескурс 'і| он:ий аў|тобус стай / шоб во ди

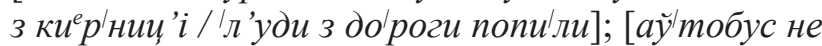
nо'битий / а воф' 'im 'iл'y отв 'ily 'am ']; ['йіхала на пос'л'едн'i сту|пен'к'i аў|тобуса // йел'i закриў]; [обйа'вили об'іңлеч ин'а паса'жир'іў в аўтобус'i].

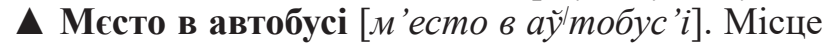
в салоні автобуса за порядковою нумерацією

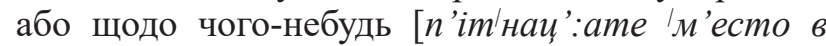

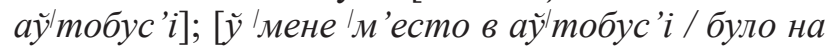
га'л'орк' $i$ / то так натру'сило / 'нач е ше $\grave{l}$ 'дос' $i$ йіду]; [y 'мене 'м'есто в аў'тобус'і на пе

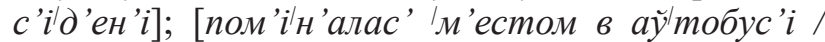
шоб недаллеко од вод 'ilŭa / бо ўккач уйус']; [м'ест

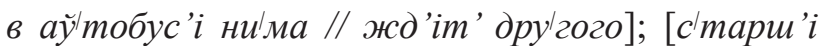
майут' право м'есто в аў|тобус' $i]$; [вофд'im 'iл' м'есто в аў'тобус'і угкаже // транз'іт!']. А Автобус «Богдан» [аў|тобус «Богдан»]. А Жовтий автобус [жоўтий аў|тобус]. Маломісний автобус марки ПАЗ. [ро'ж:иўс'а / сам ай|тобус «Бог'дан»

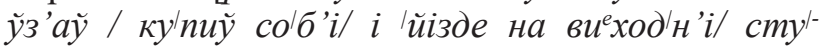
дент 'iў 'возе]; [возили та|ким ма|лен'ким ай|тобусом / «Бог'даном»]; [ко лис' 'иила и'торки уу «Бог'дан» / з'м'ір'ала доўжи'ну // то / те'пера 'дала m'іл'і|фон / $i$ хлопи' $i$ з'вон'ат' / 'кажут' // на аў|тобус «Бог'дан» // 'можна заб рат' / там / при|м'ером / 'первого 'ч'ісла?]; [не ве'ликий / о'то йак дал'но'рейсовий / а ьжоуттий аў|тобус]; [пофхож на 'жоуттий аў'тобус // ну / 'марка // 'm 'іки 'б' 'ілий / a

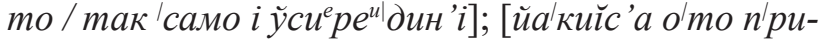
городн'ій аў|тобус 'йізде // 'жоуттй / бов виеллк' $i$ ни пусікайуm']. А Ікарусний автобус [i|карусний аў'тобус]. А Ікаріусний автобус [i кар'іусний аўтобус]. Багатомісний автобус «ікарус» угорського виробництва 1980-2000 pp. [yњ |кийіусс'кий / о'той i|карусний аў|тобус / 'тоже не 'йізде]; [і|карусн'i аў|тобуси хо дили / ппоуно]; [ там i'кар 'іусний аў|тобус не роз'вернеи'а]; [в і'кару-

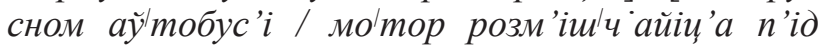
'полом саІлону / при ко|лесах]. А Пасажирьський автобус [пасажир'с'кий аў|тобус]. Автобус, призначений для перевезення людей. [запрайл'айс' Inередо м'нойу / пасајжир 'с 'кий аў|mобус // mold’i

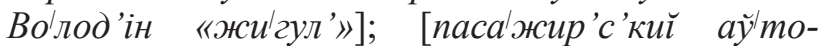
бус йак запрайл'айуm' Іазом / то / по n'рави-

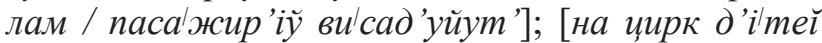
во'зили / n'p'амо на пасањжир 'с 'кому аў'тобус'і]. [у пра'вах / получч иўкатејгор 'ійуна паса'жир'с 'кий $\left.a y{ }^{\prime} m о б y c\right]$. А Рейсовий автобус $[\mid$ рейсовиі̆ аў'тобус]. Автобус, призначений для державних маршрутних перевезень населення 3 регламентованими рейсами. [на 'рейсовий аў|тобус сn'iз|нилас']; [рейсов'i аў|тобуси 'ход 'ат']; [ ['йіздиў 'рейсовим / бо и’'i 'ч асники / то йе / то ние|ма]; [голо'ван'іўс'кий / то

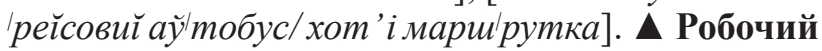
автобус [робоч ий аўтобус]. Автобус, призначений для перевезення працівників певного підпри-

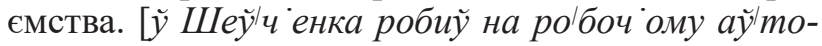
бус' $i]$; [Кол'іс ник роббоч им аў'тобусом до'йарок соби'райе]; [дл'а ро'ботник'iу / m'реба на ро'боч ий аў|тобус до Іпошти цти / на 'вос'ім 'ранку]. А

Шкільний автобус [шк' іл'|ний аў|тобус]. Автобус, призначений для перевезення школярів. [з Л' убо

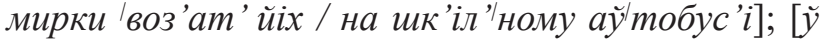

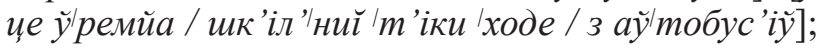
[закрили шиколи / то 'д’iтu 'йіхн'іо / me'пер до нас / на шк'іл'ному аў|тобус' $i$ 'йізд’аm']. А Автобус гармошкою [аў|тобус гар'мошкойу]. Об'єднаний двома салонами автобус фірми "Ikarus", що використовувався для перевезення пасажирів (в основному в містах). [aў|тобусом з гар|мо- 
шкойу / доуггим та|ким / на 'вибори 'йіздили]; [дл'а

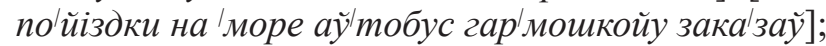
['m 'iки у у Ігород'i аў'тобуси гар мошкойу / бо там же ж' ' ' уду / m'мa]. А Права на автобус [пра ва на аўтобус]. А Категорія на автобус [кате гор'ійу на аў|тобус]. \ Категорія на пасажирський автобус [кате|гор'ійа на пасажир'с'кий аўтобус]. Категорія професійного рівня водія (категорія “D”), наявність якої дозволяє водієві керувати автобусом. [не n'росто пра'ва / а пра'ва на айlmoбус // ие ж аўтоппарк]; [mеlпер у 'Бурс'i / даже пра'ва на ай'тобус 'можна здат ']; [уे 'Добр'i здау на катецгор 'ійу на аўтобус]; [m реба катејгор 'ійа на аў|тобус / $i$ тофд’ $i$ понойл'ат' йійі / Ікажд’ $i$ три Ігода]; [од|криў кате Іор'ійу на аў|тобус]; [y пра'вах / получч иў катејгор 'ійу на паса'жир'с 'кий ай|тобус]; [катецгор 'ійу на пасањжир 'с 'кий аўlто-

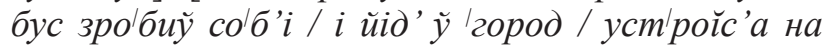
мариірутку]; [йак катејгор 'ійа на паса'жир'с'кий аў|тобус / то "каџмази» не 'вод'ат' // ие не та кате'гор'ійа]; [melnер $i$ за гра'нии'ойу не проппадеш / бо катецгор 'ійа на пасањжир 'с 'кий ай|тобус / ие кругом 'нада]. На одинацятом[у] автобусі, зі сл. їздить, добираться, жарт. Пішки, на противагу будь-яким транспортом. [йаккй там айlтобус? // уусе одм'iнили // 'т'іки на офдинач'атом аўтобус' $i$ 'л'уди 'йізд'ат ']; [сту'дент жеж / то на о'динаи'атому айтобус'і добираўс'а с Помош'нойі]; [на офдинаи'атий аў|тобус / уюе не pouly'imyüy]. \ Три автобуса навхрест [три аўтобуса наўхрест]. Незначна кількість або й відсутність транспорту, що курсує дорогами. [me'nер три ай'тобуса 'науххрест 'йізд’ ат' / a бу'ла ж / malка с'тани'ійа!]. Незначна кількість автобусів (на балансі автопарку). [скоро тили до тр'ох ай|тобус'іў 'науххрест // 'тендер / $і$ у сее!].

АВТОБУСНИЙ [аўтобусниї], a, е, прикм. 1. Те, що є частиною автобуса. [ай|тобусне |колесо]; [m'p'існуте ай'тобусне ст 'ікاло]; [mа то йа / аўlmoбуснойу дверкойу прибиў пал' 'u' $а]$. 2. Той, що стос. системи автобусного руху. [ка'c'ip 'робе аўlтобусну про'в'ірку]; [рух ай|тобусний / буў $і$ унноч $i]$; $\boldsymbol{\Delta}$ Автобусна аварія [аўтобусна авар'ійа]. [там ай|тобус пере виер'нуцус'а / айтобусна а вар 'ійа];

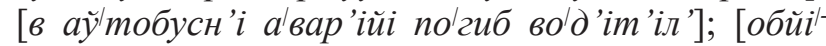
жали аж ку'в'етом / бо аўтобусна а'вар'ійа]. А Автобусний водій [аўтобусний вод'ій]. Водій автобуса. [ви айlтобусний вод'ій чи nросто?]; [догово'p'aйтес'з аўlтобусним во'д 'ійом ]; [ а аўlтобусний вод'ій / cmolüiт' вес' 'б'ілиі]. А Автобусна зупинка [аўтобусна зупинка]. А Автобусна остановка [аўтобусна останоўка]. 1. Спеціально відведене й обладнане місце, призначене для посадки чи висадки пасажирів автобуса. [clход'me а'бо 'коло 'пошти / а'бо на аў|тобусн'i зу'пинк'i // йа у циентр'i / |коло моста / не сттану / бо там n’id |гору]; [ай|тобусна оста|ноўка // $i$ ўнизу

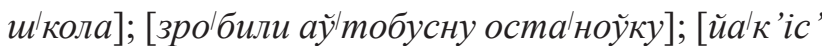

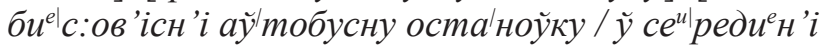

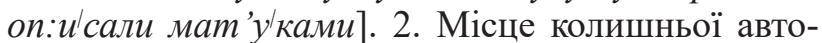
бусної станції (нині не функціонує), де за традицією зупиняються транзитні рейсові автобуси.

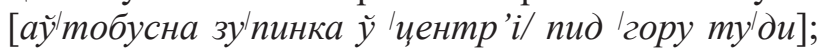

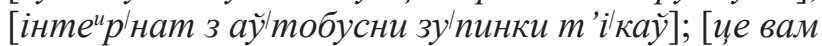

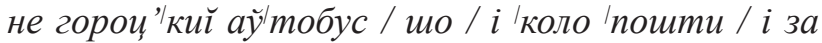
мос'том // с'тану аж на аў|тобусн'i оста'ноук'i]. А Автобусна станція [аўтобусна станц'ійа]. Спеціально обладнане місце зупинки автобусів, призначене для посадки чи висадки, обілечення пасажирів автобуса. [була аўтобусна c'тани'ійа / a mеlпер оста'ноўка]; [на аў|тобусн' $i$ c'тани'ійі ска зали / шо 'с'одн'i/ аўтобус'іў гет' ни 'буде]; [год mpии'ат' пророббила каاс'іром / на ай’тобусн'i с'тани'ійi]. А Автобусний парк [аў'тобусний парк]. Експлуатаційне підприємство, що займається технічним обслуговуванням автобусів, забезпечує ними транспортні перевезення. [в ай'тобусний парк йіде аў|тобус // виходим!]; [в аў'тобусном Іпарку Ігайки к'руте]; [ўс'у жизн' проробила бугалтером в ай|тобусному 'парку].

Висновки. Запропонований аспект удокладнення теоретичних уявлень про колокації в говірковому дискурсі спостерігається в разі дескрибування говірки у вигляді тезауруса говірколінгварію вилучених із мовленнєвих текстів колокацій як окремих мовних одиниць саме 3 урахуванням граматико-синтагматичних зв'язків та опис колокаційної складової частини в лексичній системі говірки. Укладання окремої колокаційної лексикографічної системи можливе в монографічному описі говірки як мовної системи, з використанням корпусного методу як єдино правильної методологічної основи дослідження колокацій. Вокабуляр тезауруса, фрагмент якого подається, базується на токенізації, своєрідній декомпозиції текстового матеріалу на ряд мовних одиниць - слів та колокацій тощо. За такого методу лексикографування застосовуються дистрибутивний i контекстологічний методи. У вокабулярії тезауруса колокації кваліфікуються як семантичні графи або смислові одиниці тексту.

Попередній аналіз говіркових даних виявляє значну кількість конструкцій-колокацій, що вирізняються і яскраво вираженою граматичною природою, і стійким характером, і статистичною представленістю в усному колективному мовленні, що є показником таких активних процесів сучасної української мови, як граматикалізація й ідіоматизація. Наш науковий оптимізм дозволяє прогнозувати використання тезауруса говірки як бази для укладання окремої колокаційної лексикографічної системи, що представить ще одну 3 подальших його аспектних екстраполяцій. 


\section{ЛІТЕРАТУРА}

1. Бобкова Т.В. Теоретико-методологічні підходи до вивчення колокацій у сучасному мовознавстві. Вісник Київського начіонального лінгвістичного університету. Серія «Філологія». 2014. Т. 17. № 2. C. $14-22$.

2. Бобкова Т.В. Корпусний словник колокацій : методика укладання. Наукові записки Національного університету «Острозька академія». 2015. Вип. 52. С. 39-41.

3. Громко Т.В. Моноговірковий лексикографічний комплекс як сучасна лінгвістична технологія. Мова. 2020. № 34. С. 11-17.

4. Громко Т.В. Сучасна текстографія діалектоносіїв степової говірки. Наукові записки. Серія «Філологічні науки». Кропивницький : КОД, 2019. Вип. 175. С. 29-33.

5. Громко Т.В. Тезаурус говірки як показник ії онтологічного статусу. Вчені записки Таврійського національного університету імені В.І. Вернадського. Серія «Філологія. Соціальні комунікаиії». Київ, 2020. Т. 31 (70). № 2. Ч. 1. С. 1-6.

6. Левицкий В.В. Семасиология. Винница : Новая книга, 2006. 508 с.

7. Рахилина Е.В., Кузнецова Ю.Л. Грамматика конструкций: теории, сторонники, близкие идеи. Лингвистика конструкций / отв. ред. Е.В. Рахилина. Москва : Азбуковник, 2010. С. 18-81.

8. Хохлова M.В. Экспериментальная проверка методов выделения коллокаций. Slavica Helsingiensia 34. Инструментарий русистики: корпусные подходы. 2008. С. 343-357.

9. Шкурко В.В. Лексикографічний агент екстракції колокацій у природномовному тексті. Вісник Київського начіонального університету ім. Т. Шевченка. Серія «Літературознавство. Мовознавство. Фольклористика». 2012. № 28. С. 31-35.

10. Firth J.R. Papers in Linguistics, 1934-1951. Oxford University Press, 1957. 233 p.

11. Goldberg A.E. Constructions: A Construction Grammar Approach to Argument Structure. Chicago : University of Chicago Press, 1995. 265 p.

12. Teubert W. Linguistique de Corpus: un Alternative. Semen. Besarnon : PUFC, 2009. Vol. 27. P. 130-152.

\section{REFERENCES}

1. Bobkova T.V. (2015) Teoretyko-metodolohichni pidkhody do vyvchennia kolokatsii u suchasnomu movoznavstvi [Theoretical and methodological approaches to the study of collocations in modern linguistics]. Visnyk Kyivskoho natsionalnoho linhvistychnoho universytetu. Seriia: Filolohiia. Vol. 17(2). P. 14-22.

2. Bobkova T. (2015) Korpusnyi slovnyk kolokatsii: metodyka ukladannia [Corpus dictionary of collocations: methods of compiling]. Naukovi zapysky Natsionalnoho universytetu "Ostrozka akademiia". Vol. 52. P. 39-41.

3. Hromko T.V. (2020) Monohovirkovyi leksykohrafichnyi kompleks yak suchasna linhvistychna tekhnolohiia [Monosubdialect lexicographic complex as a modern linguistic technology]. Mova. Vol. 34. P. 11-17.

4. Hromko T.V. (2019) Suchasna tekstohrafiia dialektonosiiv stepovoi hovirky [Modern textography of idiom carriers of the steppe subdialect]. Naukovi zapysky. Seriia: Filolohichni nauky. Vol. 175. Kropyvnytskyi. P. 29-33.

5. Hromko T.V. (2020) Tezaurus hovirky yak pokaznyk yiyi ontolohichnoho statusu [Thesaurus of subdialect as an indicator of its ontological status]. Vcheni zapysky Tavriiskoho natsionalnoho universytetu imeni V.I. Vernadskoho. Seriia: Filolohiia. Sotsialni komunikatsii. Kyiv. Vol. 31 (70). № 2. Ch. 1. P. 1-6.

6. Levytskyi V.V. (2006) Semasyolohyia [Semasiology]. Vynnytsa : Novaia Knyha. 508 p.

7. Rakhylyna E.V. \& Kuznetsova Yu.L. (2010) Hrammatika konstruktsyy: teorii, storonniki, blizkiye idei [Grammar of constructions: theories, supporters, close ideas] [v:] Lynhvystyka konstruktsyi / Otv. red. E.V. Rakhylyna. Moskva. P. 18-81.

8. Khokhlova M.V. (2008) Eksperymentalnaia proverka metodov vydeleniya kollokatsyi [Experimental verification of collocation identification methods]. Slavica Helsingiensia 34. Instrumentariy russistiki: korpusnyye podkhody. P. 343-357.

9. Shkurko V.V. (2012) Leksykohrafichnyi ahent ekstraktsii kolokatsii u pryrodnomovnomu teksti [Lexicographic agent of collocation extraction in natural language text]. Visnyk Kyivskoho nats. un-tu im. T. Shevchenka. Seriia : Literaturoznavstvo. Movoznavstvo. Folklorystyka. Vol. 28. P. 31-35.

10. Firth J.R. (1957) Papers in Linguistics, 1934-1951. Oxford University Press. 233 p.

11. Goldberg A.E. (1995) Constructions: A Construction Grammar Approach to Argument Structure. Chicago: University of Chicago Press. $265 \mathrm{p}$.

12. Teubert W. (2013) Linguistique de Corpus: un Alternative. Semen. Besarnon : PUFC. Vol. 27. P. 130-152. 